\title{
THE ANATOMY OF SIX EPIPHYTIC SPECIES OF LYCOPODIUM
}

CONTRIBUTIONS FROM THE HULL BOTANICAL LABORATORY 189

J. BEN HILL

(WITH TWENTY-EIGHT FIGURES)

In this investigation, six epiphytic species of Lycopodium were studied. Two New Zealand species, L. Billardieri Spring. and L. varium $\mathrm{R}$. Br., with two South African species, L. verticillatum G.f. and L. Holstii Hieron., were furnished by Dr. Charles J. Chamberlain; and two forms from Samoa, L. Phlegmaria Linn. and L. carinatum Desv., were collected by Dr. W. J. G. LAND. The two species from New Zealand were identified by Dr. Jesse M. Greenman of the Field Museum, Chicago, and the remainder were identified by Dr. G. Hieronymus of Berlin. There was some doubt concerning the identity of the two forms from Samoa, since they do not correspond exactly to the descriptions of their respective species. Dr. HIERonymus suggests that each represents a new variety or subspecies. The species studied are described as growing epiphytic upon trees, with the short, vegetative branches more or less erect, and the long, slender, dichotomously branched strobili pendulous (fig. I). Most of these species are rather rare, but $L$. Phlegmaria and $L$. Billardieri are mentioned in the recent literature dealing with the morphology of the group. Since these forms are not very familiar to residents of the northern hemisphere, a short general description may serve to make this account more intelligible.

L. Holstii is a very coarse plant, with short thick stems covered with large stiff leaves. The stem is $4-6 \mathrm{~mm}$. in diameter, with a small stele $0.35 \mathrm{~mm}$. in diameter. The leaves are about $2.5 \mathrm{~cm}$. long and sharply pointed. Type material, furnished by Dr. G. HIERONymus, shows sporophylls with little or no modification from the vegetative leaves. They are not grouped in a definite strobilus, but are simply aggregated near the apex, much as in L. lucidulum.

[Botanical Gazette, vol. 58 


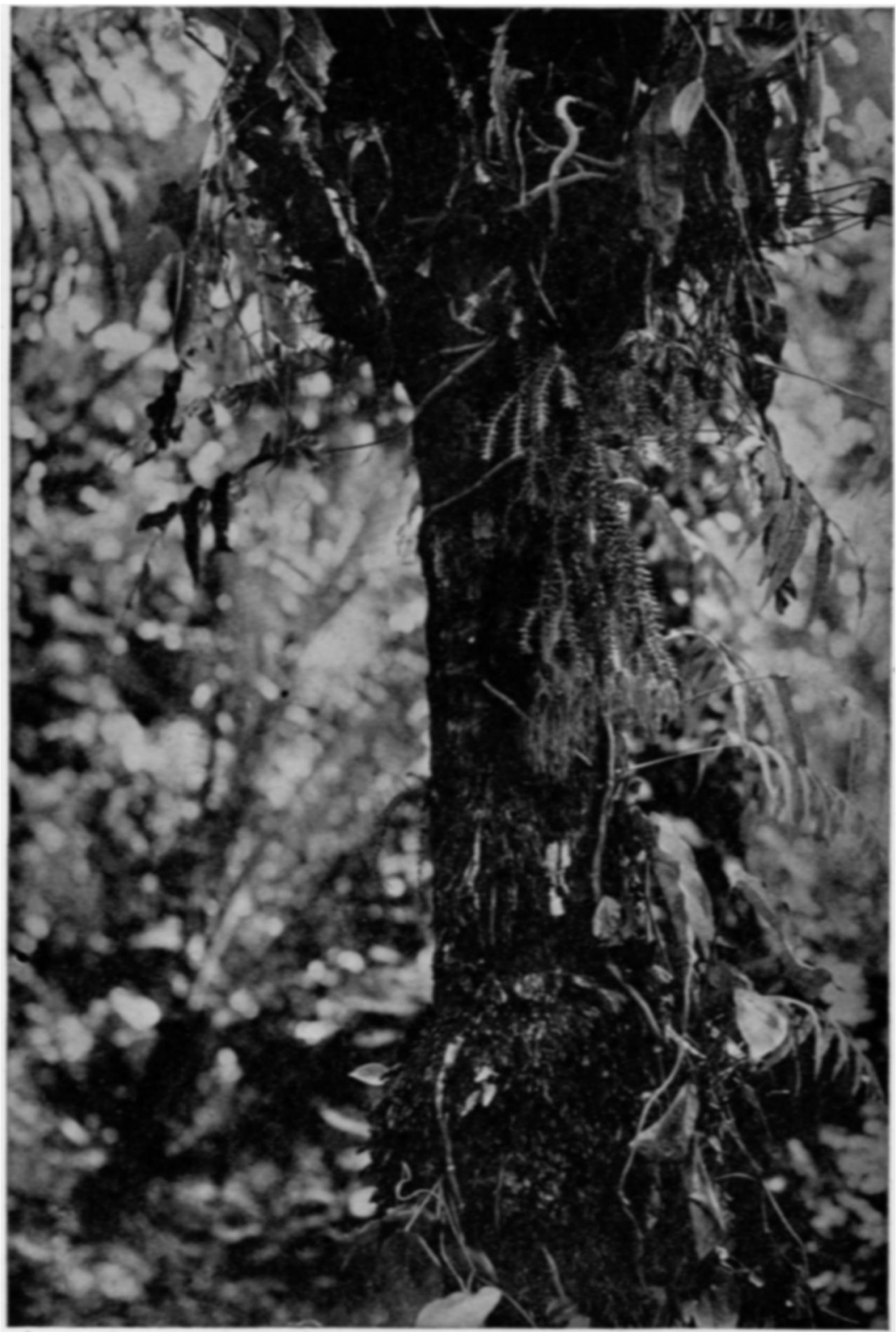

Fig. I.-L. Phlegmaria: epiphytic upon cocoanut tree; photograph of the plant in the field showing the habit of the species. by LAxD.

This content downloaded from 128.143.023.241 on August 23, 2016 22:07:51 PM All use subject to University of Chicago Press Terms and Conditions (http://www.journals.uchicago.edu/t-and- 
L. verticillatum is much more delicate, with a slender stem covered with long, slender leaves. The sporophylls are arranged in definite strobili, which are regularly dichotomously branched and attain a length of $20-40 \mathrm{~cm}$. The sporophylls show a slight modification from the foliage leaves, being smaller and more sharply pointed. Both leaves and sporophylls show spiral phyllotaxy.

L. Billardieri and L. varium resemble each other in their general appearance. Both bear long, dichotomously branched strobili with cyclic sporophylls arranged in alternating pairs, so that the outline in transverse section is square. In both species the sporophylls differ from the foliage leaves, being short and bluntly pointed. The chief gross difference in the two species is that $L$. varium is slightly coarser and the square shape of the transverse section of the strobili seems to be more definitely fixed than that of $L$. Billardieri, which produces some strobili circular in transverse section.

L. Phlegmaria is well known and needs little description. It is one of the most conspicuous examples of dimorphic leaves, the sporophylls being very small and delicate, almost membranous, while the vegetative leaves are broad and short. The strobili are very definite because of the extreme modification of the sporophylls and are circular in transverse section. Both vegetative leaves and sporophylls are sometimes cyclic in arrangement.

L. carinatum probably represents the highest specialization of any of the species studied. There is definite dimorphism of the leaves, which show the cyclic arrangement to the extent of giving even the young shoots the quadrangular appearance so characteristic of the strobili of some epiphytic lycopodiums. The strobili are also square in transverse section and dichotomously branched. The anatomical study also justifies the statement that this species represents the highest specialization of the species studied.

The material from New Zealand consisted entirely of mature stems and strobili, with no vegetative shoots. Roots were present in the material of $L$. Billardieri. The material of $L$. verticillatum consisted of several complete mature plants with both vegetative shoots and strobili, while that of $L$. Holstii was entirely vegetative. 
The two species from Samoa were complete. No prothallia nor young sporophytes were present in any of the material. An investigation of the anatomical structures of the plants offered the most interesting feature of study, and this investigation was undertaken with reference to the development of the stele and its bearing upon phylogeny. The material was studied from paraffin serial sections cut IO-I $5 \mu$ in thickness and stained in safraninanilin blue and in safranin-light green. Since the material of L. carinatum was complete, and of such a character as to show the

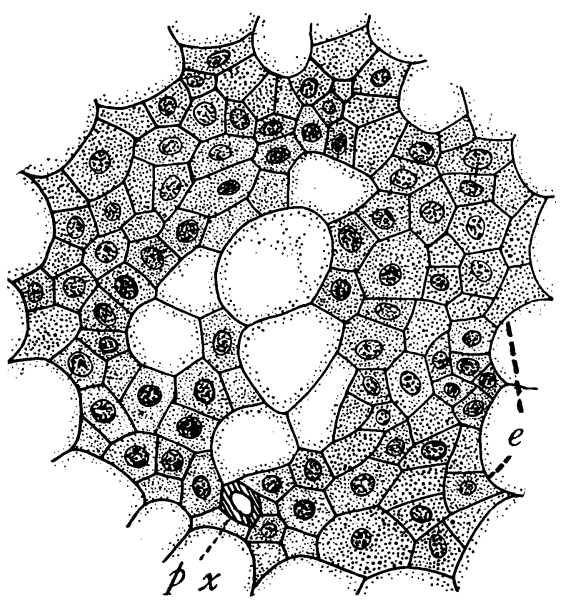

FIG. 2.-L. carinatum: transverse section of the stem near the apex, showing the organization of the young stele; $e$, inner wall of endodermal cells; $p x$, protoxylem; large cells in center are unlignified potential metaxylem cells; $\times_{500}$. structures especially well, this species was selected as a basis for description and comparison.

\section{L. carinatum}

In the apex of the strobilus of $L$. carinatum the outline of the transverse section of the young vascular cylinder is often almost square. Within the first millimeter of the stem, before any lignification of the protoxylem is recognizable, there is distinct differentiation of the tissues; not only is the cylinder organized as a region distinct from the cortex, but the elements of the tissues of the vascular system are differentiated. The large cells of the endodermis are discernible, inclosing a mass of smaller cells, part of which have abundant cytoplasm and conspicuous nuclei. This group of cells is to be differentiated into the vascular tissues.

At this stage of development there are two distinct systems of cells within the stele. The central region of the young cylinder is occupied by $5^{-}$-ro large, thin-walled, unlignified cells with vacuolate cytoplasm, forming an irregular radiating group. These are to become lignified and form metaxylem. The angles of this radiating 
mass of cells and the portions of the cylinder just within the endodermis are occupied by groups of smaller cells which have relatively very large nuclei and dense cytoplasm. These smaller cells are the parenchyma of the cylinder and will give rise to both the protoxylem and the phloem elements (fig. 2).

The cylinder of the vegetative apex is more nearly circular in outline than that of the strobilus. The two show similar differentiation and differ little excepting that the cylinder of the vegetative shoot has about twice the diameter of that of the strobilus, and the extent of the group of large cells is greater, with more numerous groups of small parenchyma cells.

In the further organization of the stele, the protoxylem is the first to be differentiated. The protoxylem points arise in irregular succession in the peripheral region of the cylinder by the lignification of some of the small cells. Generally there is only one cell lignified first, and usually this cell is situated in the second layer of cells from the endo-

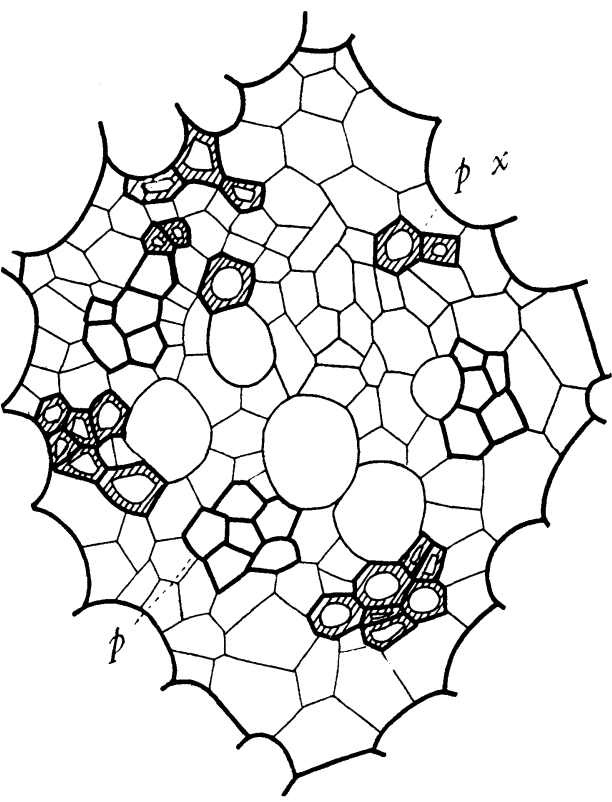

Fig.3.-L.carinatum: transverse section of the strobilus axis, showing the radial arrangement; $p x$, protoxylem; $p$, phloem; $\times_{500}$. dermis. This is followed by the lignification of some of the adjacent smaller cells similarly situated. This leaves a pericycle, at first one layer of cells in thickness. There are 2-4 protoxylem points differentiated in the strobilus apex, and a large number, generally 6 or 8 , in the vegetative apex. These points are located at the peripheral ends of the radiating strands of the central group of unlignified cells (fig. 3). This is the regular situation in the vegetative apex, but when there are only 2 protoxylem points in the strobilus apex, the relation of the protoxylem and the 
unlignified cells may vary. Often the arrangement shows the protoxylem point on each side of the cylinder, with a band of unlignified cells arranged parallel to it and just inside, while the middle of the cylinder is occupied by a band of phloem extending
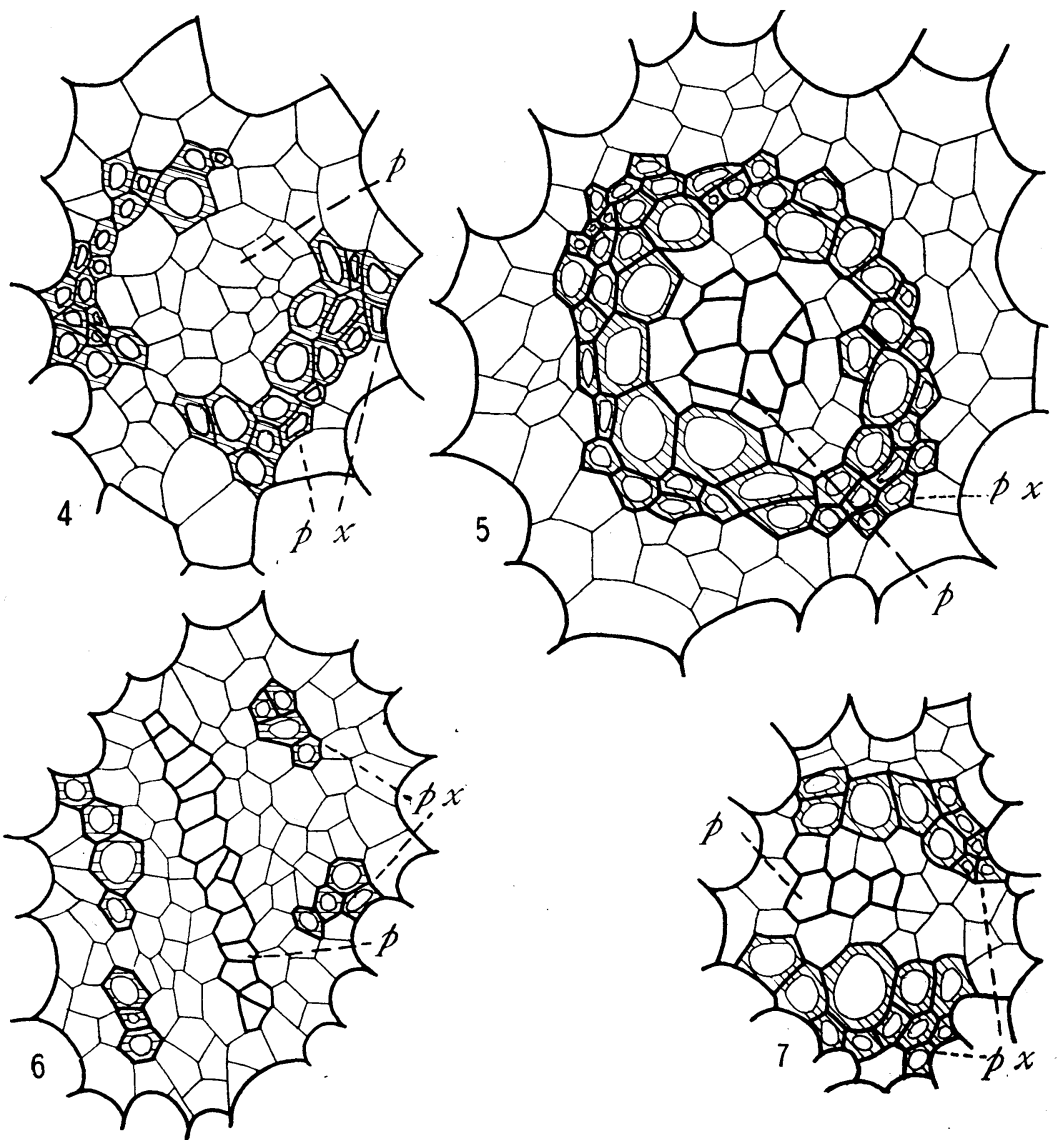

Figs. 4-7.-Fig. 4, L. carinatum: transverse section of the strobilus apex, showing the development of the parallel-banded type; $p x$, protoxylem; $p$, phloem; fig. 5 , L. carinatum: transverse section of the stele in the strobilus axis, showing the amphivasal condition, phloem in the center inclosed by a ring of xylem; $p x$, protoxylem; p, phloem; fig. 6, L. Phlegmaria: transverse section of strobilus, showing radial arrangement, with the phloem extending across the center forming a band; the same condition is also found in L. carinatum; $p x$, protoxylem; $p$, phloem; fig. 7, L. Phlegmaria: showing the development of the parallel-banded stele; $p x$, protoxylem; $p$, phloem; all $\times 500$. 
from the sides across the center (fig. 4). This gives the parallelbanded type of stele, that is, alternating parallel bands of xylem and phloem. In all of these situations there is a tendency for the protoxylem to grow around the circumference of the cylinder (figs. 8, 9), with very irregular behavior of the groups, consisting of fusions and splitting, resulting in crescent-shaped masses and even in masses completely encircling a central mass of the parenchyma and phloem, giving a type of stele resembling the amphivasal type found in monocotyledons (fig. 5).

The phloem as recognizable tissue is differentiated from the parenchyma at a somewhat later period than the protoxylem. In all of the protoxylem situations described above, the phloem arises from the small parenchyma cells located on the same circumference as the protoxylem, giving a true radial stele.

The study of the strobilus in transverse serial sections shows three types of stele: radial, parallel-banded, and amphivasal, the two latter conditions being derived from the first by modifications and specialization. These changes are not connected with branching. They are the result partly of the behavior of the protoxylem groups, but chiefly of the growth and development of the metaxylem. The young stele in the apex is organized at first with a distinct radial arrangement, the protoxylem points, 2 or 3 in number, alternating with phloem groups on the same circumference (fig. 3 ). Lower in the stem, the sections show the protoxylem extending around the periphery of the cylinder, with the developing metaxylem organized as two parallel bands, with the phloem groups at each end, extending inward and forming a central band of phloem (fig. 4). At a slightly lower level in the young strobilus, the amphivasal arrangement is found (fig. 5). This is a further modification of the parallel-banded arrangement. It is formed by the continued peripheral growth of the xylem until a complete ring is formed inclosing the phloem. This ring remains intact only a short distance in the stem. At a lower level it appears broken up into the parallel-banded types, and this condition still lower passes into the distinctly radial arrangement. Since the parallel-banded and radial arrangements are found both above and below the amphivasal, the latter passing into the parallel-banded, and that 
into the radial, it is clear that these various conditions are all modifications of the radial arrangement (fig. 3). In most cases the amphivasal condition is not attained. This occurs where the xylem grows around only one end of the band of phloem, giving a crescent-shaped xylem (fig. 9). This arrangement may be either an intermediate condition between the parallel bands and the amphivasal situation, or it may represent the final development at that point and, breaking up, return to the parallel-banded type without the formation of the amphivasal. These modifications seem to be entirely confined to the strobilus cylinder. In the vegetative stems and in the vegetative part of the stem which bears the strobilus, there is no evidence of the modifications of the stele which are so characteristic of the strobilus. All vegetative parts are radial as to their stelar structure excepting where this condition is modified by branching.

At the base of the vegetative stems roots leave the stele, and pass downward through the cortex for some distance before finally: passing out of the stem. These roots show a peculiar tendency to form a ring of xylem resembling the ring of xylem in the stem.

\section{Phlegmaria and L. varium}

Both these species greatly resemble $L$. carinatum in the tendency of the strobilus to develop the parallel-banded type of stele, by the peripheral growth of protoxylem and by the development of the metaxylem at the sides of the cylinder, leaving the central portion occupied by the phloem. This tendency to the peripheral growth of the xylem is especially marked in $L$. varium, where even in the mature stem it is sufficiently extensive to inclose one-third to one-half of the stele in certain portions for a considerable distance (fig. I5). L. Phlegmaria shows many crescent-shaped masses of xylem in the strobilus stele (figs. 8, 9), which nearly close, but it seldom if ever fully attains the amphivasal condition reached by L. carinatum. The parallel-banded type in L. varium is not always derived from the radial arrangement as it seems to be in $L$. carinatum. The apex shows distinctly two methods of organization of the stele. One is the radial as described for L. carinatum (figs. Io, II). The other is the method in which the radial arrangement 

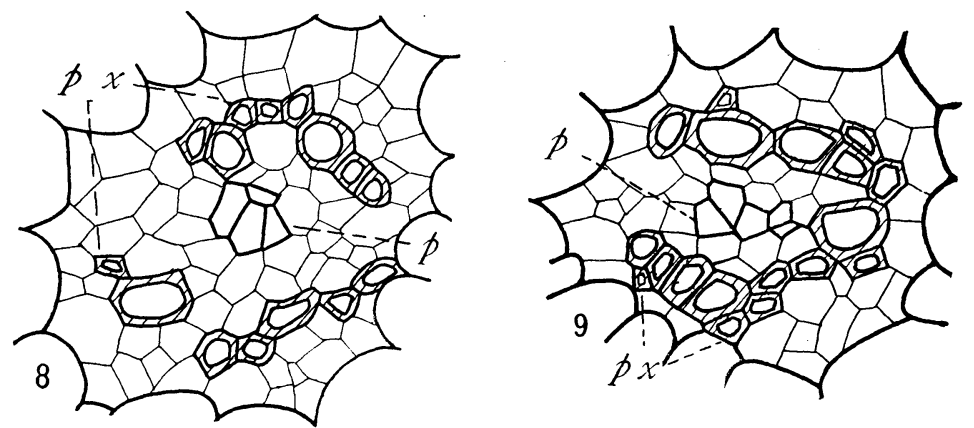

Figs. 8, 9.-L. Phlegmaria: transverse sections in the same series, showing the development of the crescent-shaped xylem mass from the parallel-banded type; the same method of development is found in L. carinatum, which carried farther gives the amphivasal condition; $p x$, protoxylem; $p$, phloem; $\times_{500}$.

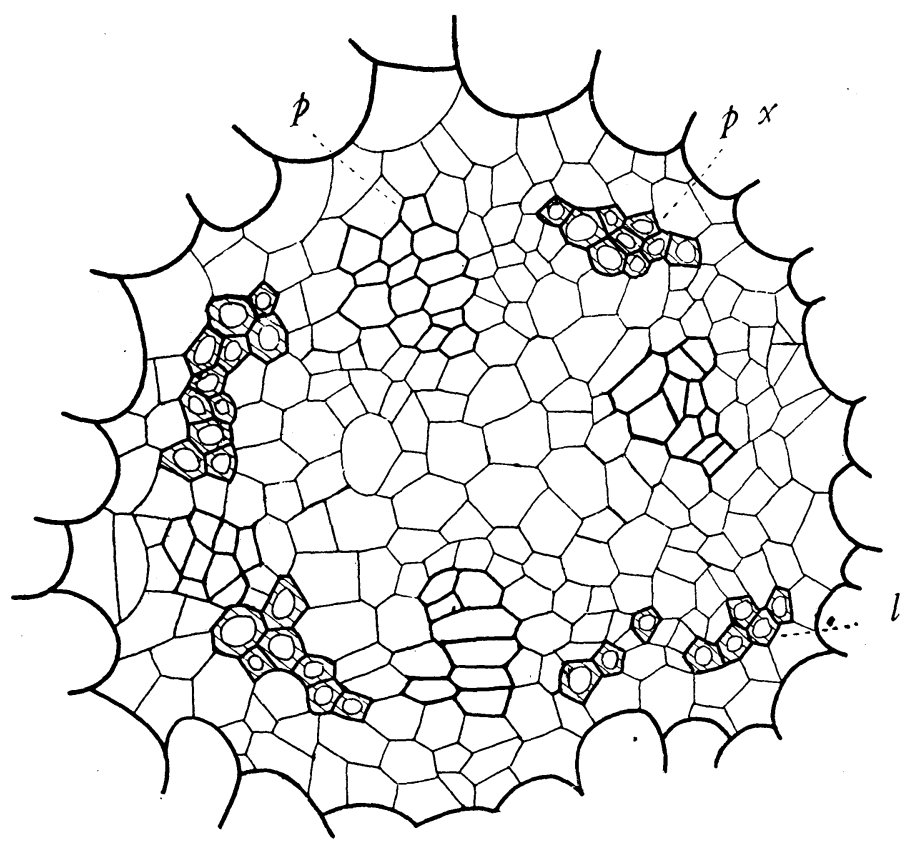

Frg. ro.-L. varium: transverse sections of the strobilus apex, showing the radial arrangement; $l$, leaf trace; $p x$, protoxylem; $p$, phloem; $\times_{500}$. 
does not appear at first. There is one protoxylem point on either side with the phloem between, which develops directly into the parallel-banded type (figs. I2, I3). These parallel bands of xylem may develop into crescent-shaped xylem masses. The crescentshaped xylem is a high development of the parallel-banded type of stele, formed, as in L. carinatum, by the growth of xylem around one end of the phloem (fig. 9). The mature stem and the vegetative

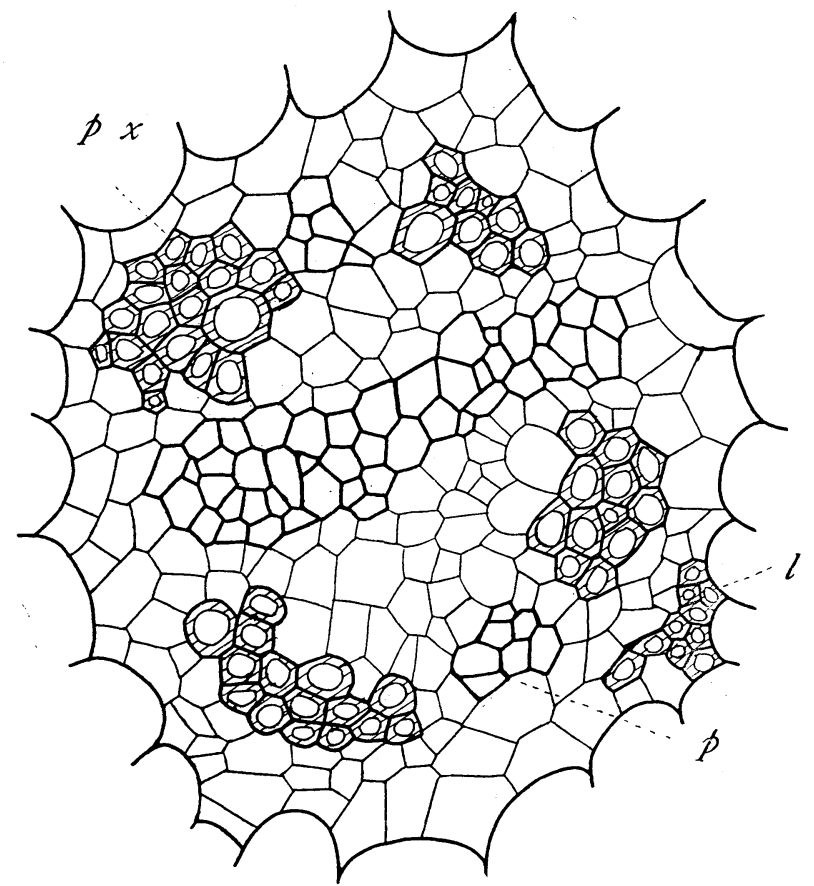

FIG. Ir.-L. varium: section in the same series as fig. Io, showing the development of the parallel-banded type from the radial; $l$, leaf trace; $p x$, protoxylem; $p$, phloem; $\times 500$.

stem of $L$. Phlegmaria are characterized by the true radial arrangement (fig. I4). The material of $L$. varium was entirely strobilusbearing, but the vegetative portions show the radial arrangement (fig. 15). The type of the stele in all cases in these species, as in L. carinatum, is determined by the growth of the metaxylem.

As an aid to a better understanding of these stems, clay models were made of the xylem portions of the steles by studying serial 

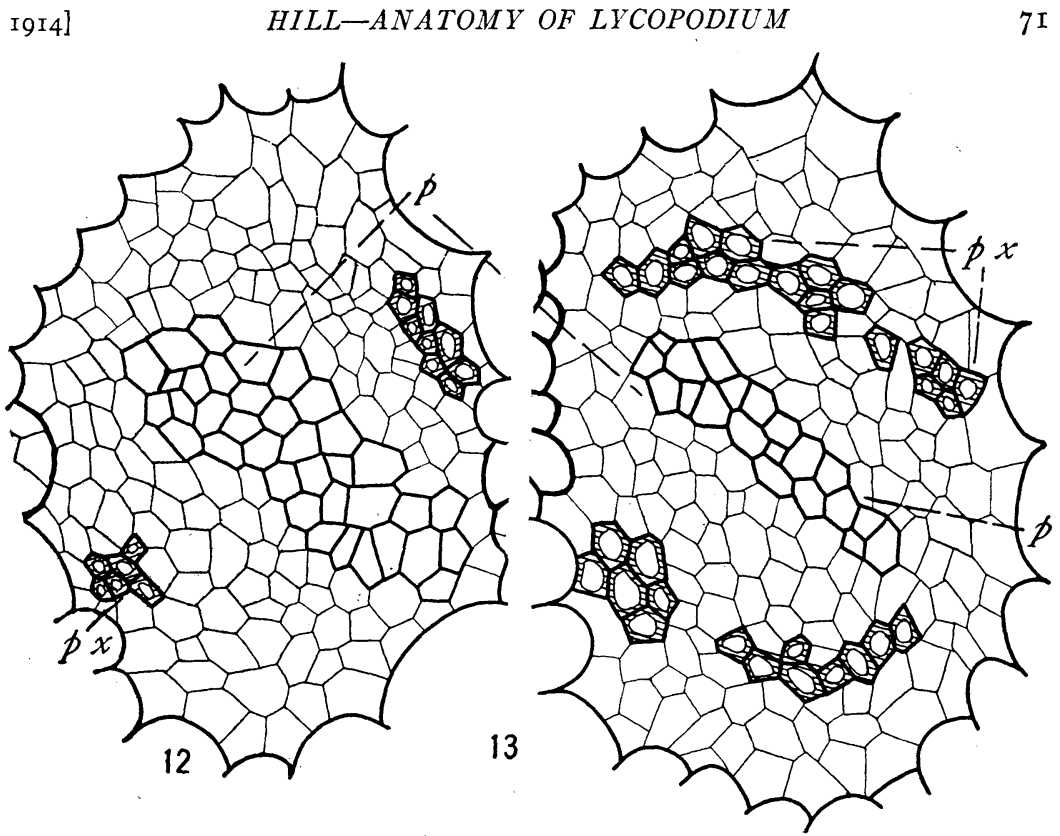

FIGS. I2, 13.-L. varium: transverse sections of strobilus apex, showing the parallel-banded type of stele developing directly without passing through the radial arrangement; $p x$, protoxylem; $p$, phloem; $\times_{500}$.

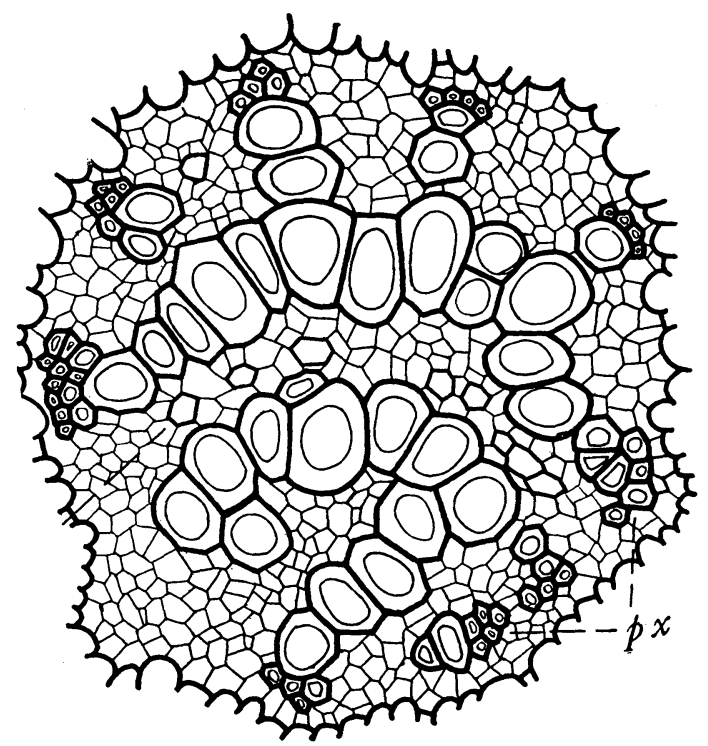

Fig. I4.-L. Phlegmaria: transverse section of mature vegetative stem; $p x$, protoxylem; $p$, phloem; $\times 185$. 
sections and building up the corresponding structures in clay (figs. I6, I7). Vegetative portions were selected for reproduction and the method of study gave some interesting results. The model of the stele of $L$. varium was almost a complete cylinder, with occasional breaks in the peripheral shell of xylem (fig. I6). This structure is due to the growth of the xylem around the periphery. There were some indications that this growth is related

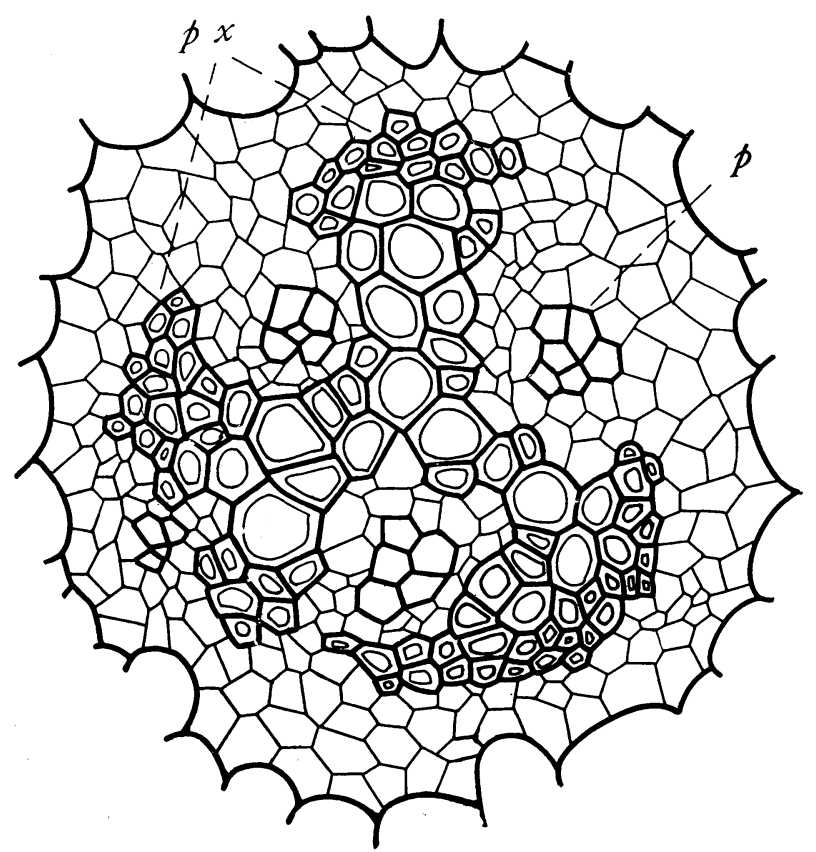

FIG. 15.-L. varium: transverse section of the strobilus-bearing branch, showing the radial arrangement; $p x$, protoxylem; $p$, phloem; $\times_{300}$.

to the passing out of the leaf traces, since often there would be a leaf trace at the point of meeting of two of the peripheral growths. There was too much irregularity in the matter of leaf traces to justify making any definite statements, since leaf traces pass off from the protoxylem points and from the peripheral growths also, with no apparent general relation to the growth of the xylem. The study of the clay models showed branching and fusions of the protoxylem points to be quite common. The relation of xylem 
and phloem was evident in the model; the branching of the xylem was often followed by branching of the phloem groups and xylem fusions by phloem fusions. Frequently the peripheral
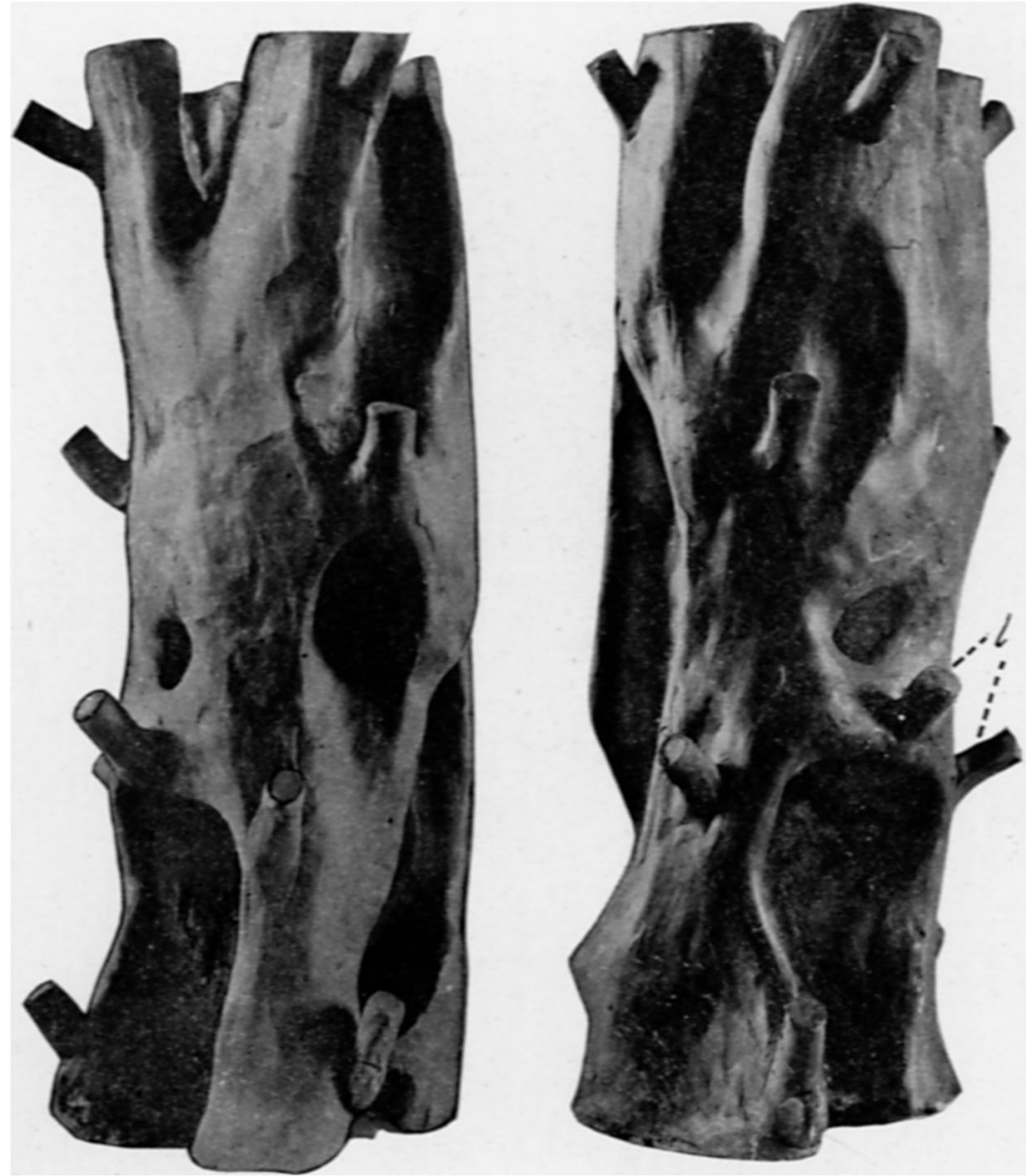

Fic. 16.- $L$. aarium: photographs of the clay models of the stele; the base is started at the portion of the stem represented in fig. 15; the projections represent the leaf traces which pass out indiscriminately from the stele; $l$, leaf trace.

growth of the xylem cut off phloem on the outside of the xylem, and sometimes phloem seemed to arise outside when the xylem was indented. 

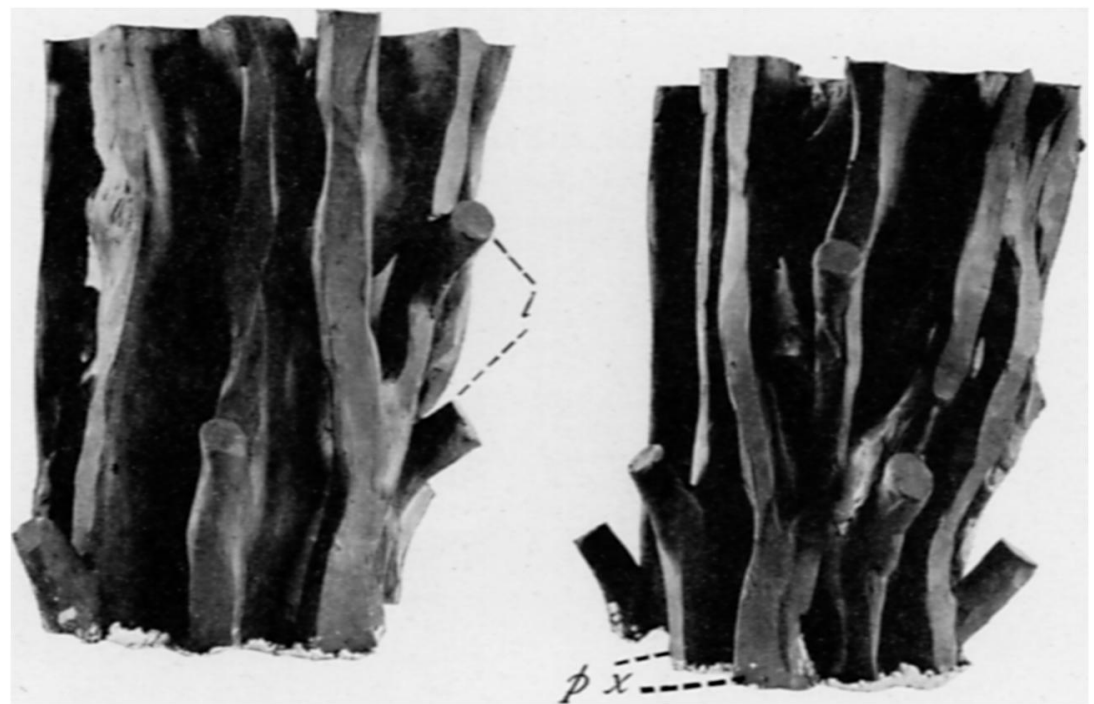

Fig. 17.-L. Phlegmaria: photographs of the clay models of the stele; the ridges represent the projecting protoxylem groups which fuse and branch irregularly; leaf traces are represented by projections; $p x$, protoxylem; $l$, leaf trace.

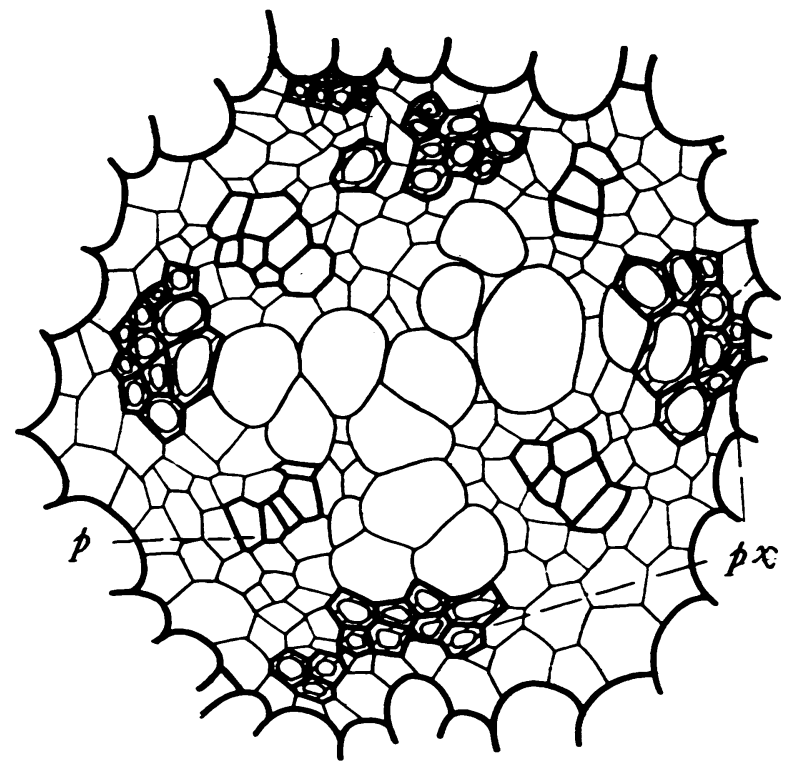

FIG. 18.-L. Billardieri: transverse section of the strobilus apex, showing the radial organization of the stele; protoxylem groups alternating with phloem; the center of the stele is occupied by the unlignified potential metaxylem cells; $p x$, protoxylem; $p$, phloem; $X_{5} 00$. 


\section{Billardieri}

The organization of the strobilus in this species is distinctly radial, and this condition was constant in all the material examined (fig. I8). The further development of the metaxylem also results in a very regular structure for the stem. This structure consists of several radiating bands of xylem with phloem groups between them. The xylem also has a great tendency to form an almost

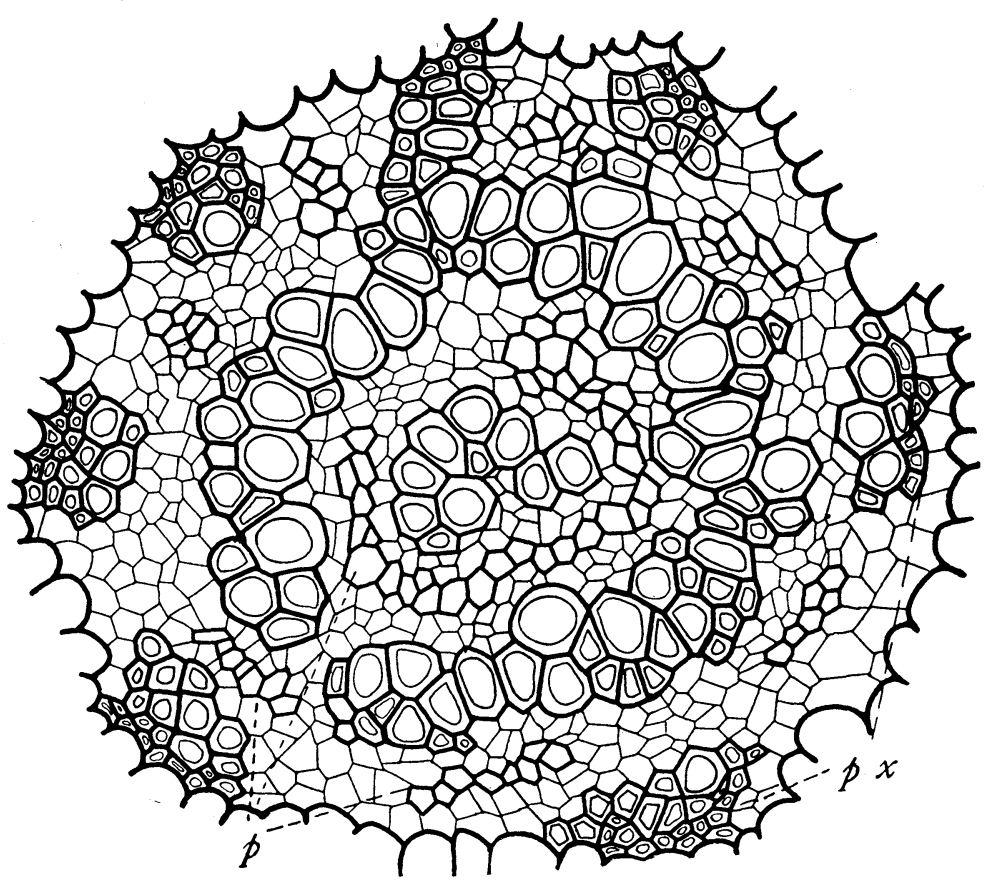

FIG. 19.-L. Billardieri: transverse section of a mature stem, showing the inner xylem ring; $p x$, protoxylem; $p$, phloem; $\times 185$.

complete ring inside the stele. The center of this ring may be occupied by a single isolated strand of either phloem or. xylem. The development of the ring is dependent entirely upon the behavior of the metaxylem and not upon the peripheral growth as in $L$. carinatum, for it is not peripheral to the stele, but is located inside the periphery, forming an inner ring with radiating masses of xylem which extend to the circumference of the vascular cylinder (fig. I9). 

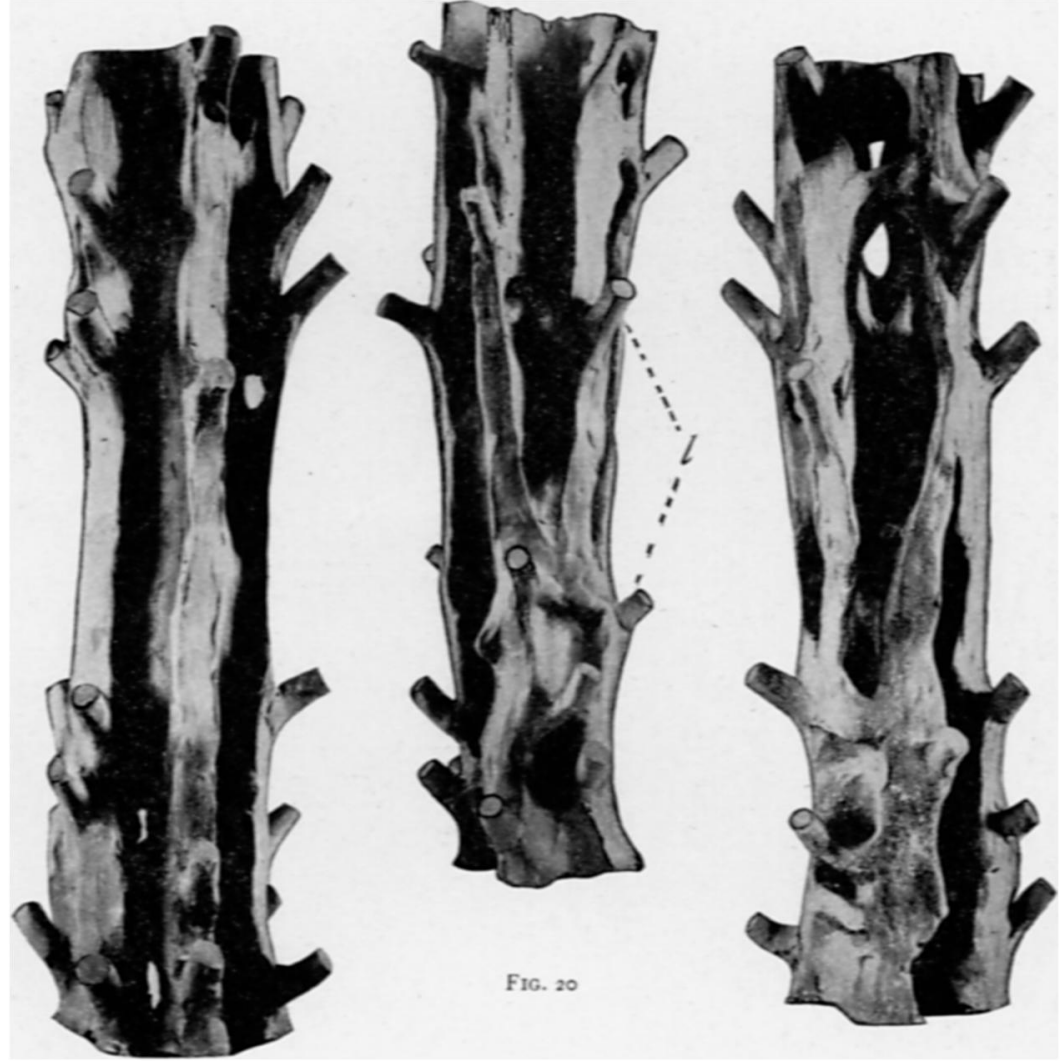

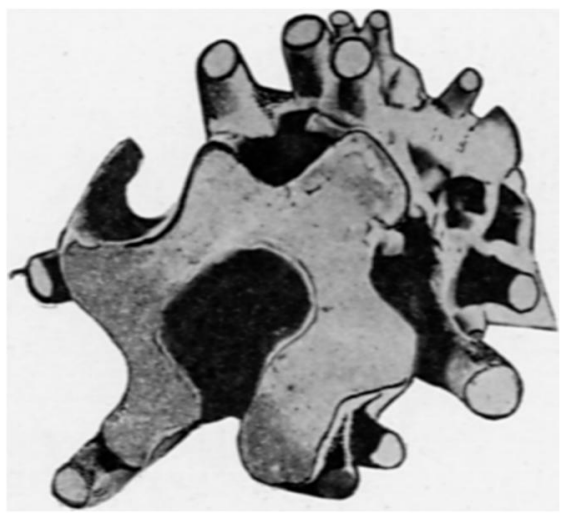

Fic. 28

FIG. 20.-L. Billerdieri: photagraphs of the clay model, showing the irregular behavior of the protoxylem groups and their relation to the leaf traces; the protoxylem groups bere show both fusions and splitting; $l$, leaf trace.

Fic. 21.-L. Billardieri: photograph showing an end view of the model shown in fig. 20 . 
This is the usual condition of the vegetative portions of the stem and can be designated as a radial arrangement. A clay model of the xylem portions of the stele was made, and it shows something of the xylem behavior in the stem (figs. 20, 2I). No young vegetative shoots were present for comparison in this species, but the mature vegetative stem, bearing strobili, shows the characteristic structure of the stem (fig. 19). The phloem is distinct and is recognizable earlier than in most of the species.

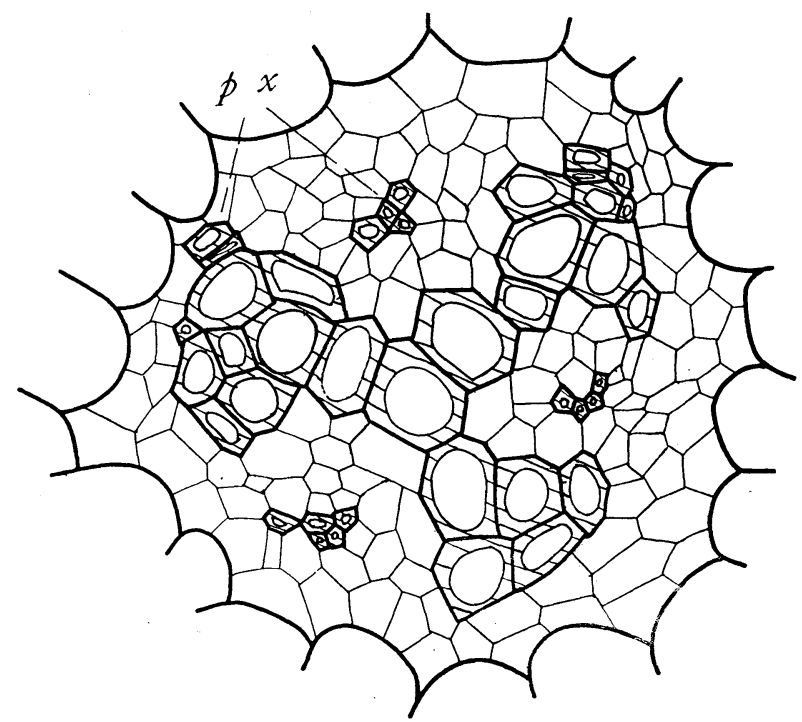

FIG. 22.-L. Holstii: transverse section of the stele of a young shoot, showing the radial arrangement; $p x$, protoxylem; $\times_{500}$.

Cortical roots occur toward the base of the stem as described in $L$. carinatum, but their structure is similar to those described for L. pithyoides. ${ }^{\mathrm{x}}$

\section{Holstii}

The material of this species was entirely vegetative, and of the vegetative shoots there were very few young ones. From a study of a limited number of slides, it appears that the stele is organized with a rather large number of protoxylem points (about 8). The

I Stokey, Alma G., The roots of Lycopodium pithyoides. Bot. Gaz. 44:57-63. pls. 5, 6. 1907 . 
central portion of the stele is occupied by large unlignified cells which are slowly thickened into metaxylem. The phloem seems to arise irregularly near the periphery and is not easily recognized when young. In the young shoot examined, the stele became radial toward the base (fig. 22). Here there were fewer protoxylem points also, 3 or 4 in number, and part way up the stem there was an isolated xylem strand as occurs in L. Billardieri (fig. I9). The

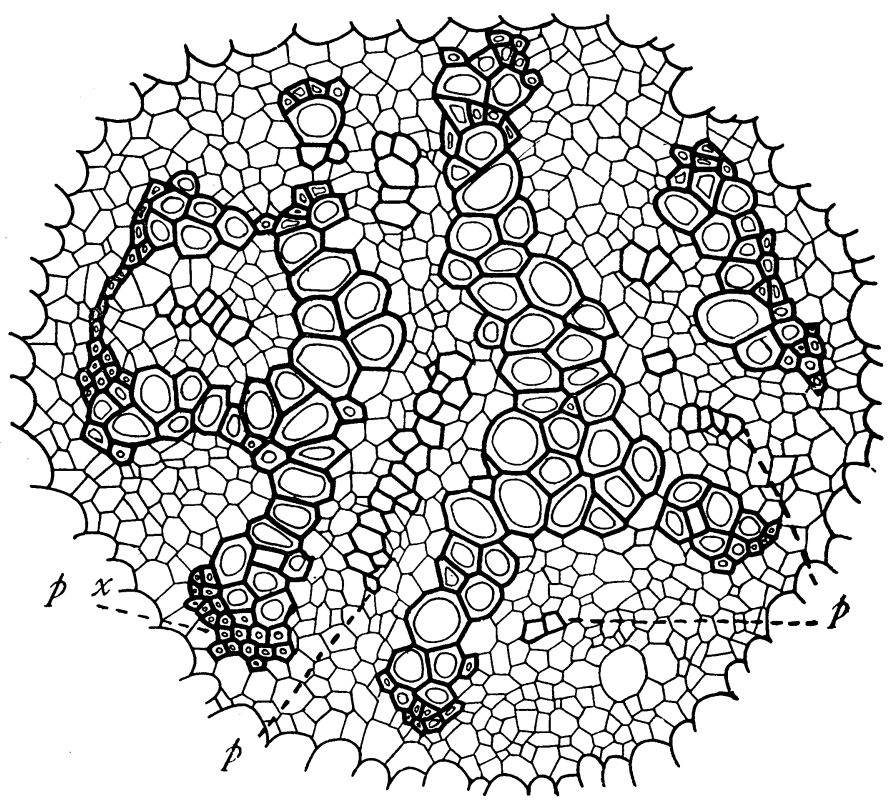

FIG. 23.-L. Holstii: transverse section of mature stem, showing parallel-banded type of stele; phloem scattered irregularly between the xylem bands; $p x$, protoxylem; $p$, phloem; $\times 185$.

distinctly radial arrangement extended to the base of the shoot where it joined the main plant.

In the fully mature vegetative stem there is an irregular parallelbanded type of stele (fig. 23) differing in appearance from that described for L. verticillatum, and more developed than those in the strobilus of L. carinatum. The phloem in the mature stele is scattered in patches throughout the parenchyma bands between the xylem groups. 


\section{L. verticillatum}

The stele of the strobilus in this species is characterized by the differentiation of very few protoxylem points, 2 or 3 groups being usual (figs. 24, 25). It differs from the other species in not being radial at the apex. The organization of the stele in the strobilus seems to be generally of the parallel-banded type from the first, with a phloem group between two xylem bands, as sometimes occurs in $L$. varium, and this develops into the crescent-shaped xylem mass with phloem in the middle, as has been described for
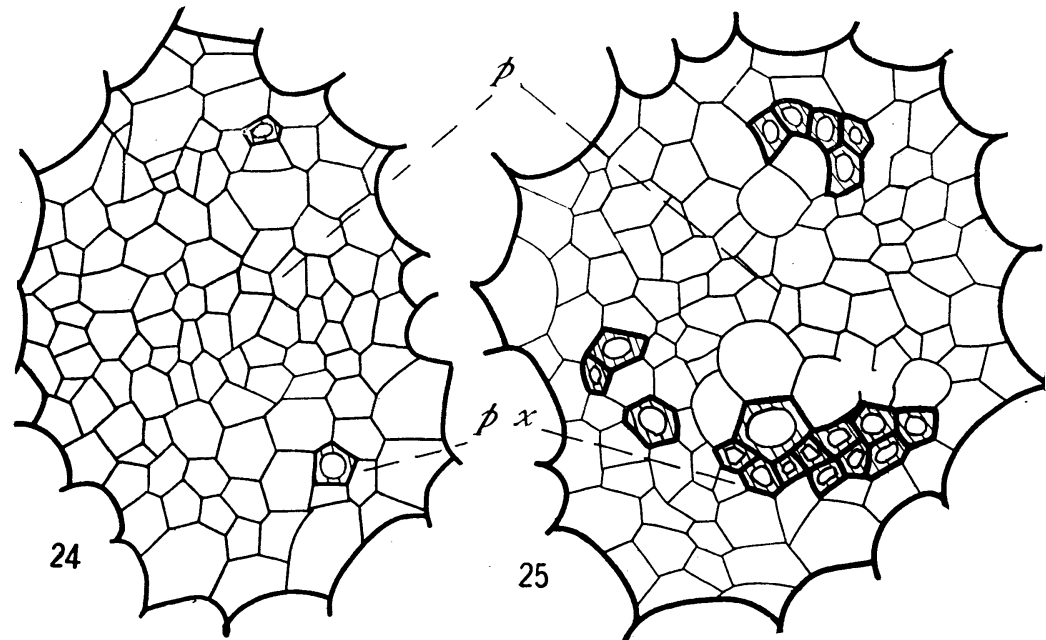

FIGS. 24, 25.-L. verticillatum: transverse sections in series, showing the protoxylem groups and the developing parallel bands; $p x$, protoxylem; $p$, phloem; $\times 500$.

the other species (figs. 9, 26). This crescent-shaped mass breaks up into the parallel-banded type, and then later at a lower level in the strobilus axis, the metaxylem begins to grow inward and breaks up the phloem band, forming a distinctly radial arrangement (fig. 27). The phloem in this species is very difficult to recognize, and often even in the mature stem the extent of the phloem is uncertain.

The mature vegetative stem is of an irregular parallel-banded type with rather numerous protoxylem points. The phloem is very limited in amount, and is scattered somewhat irregularly 

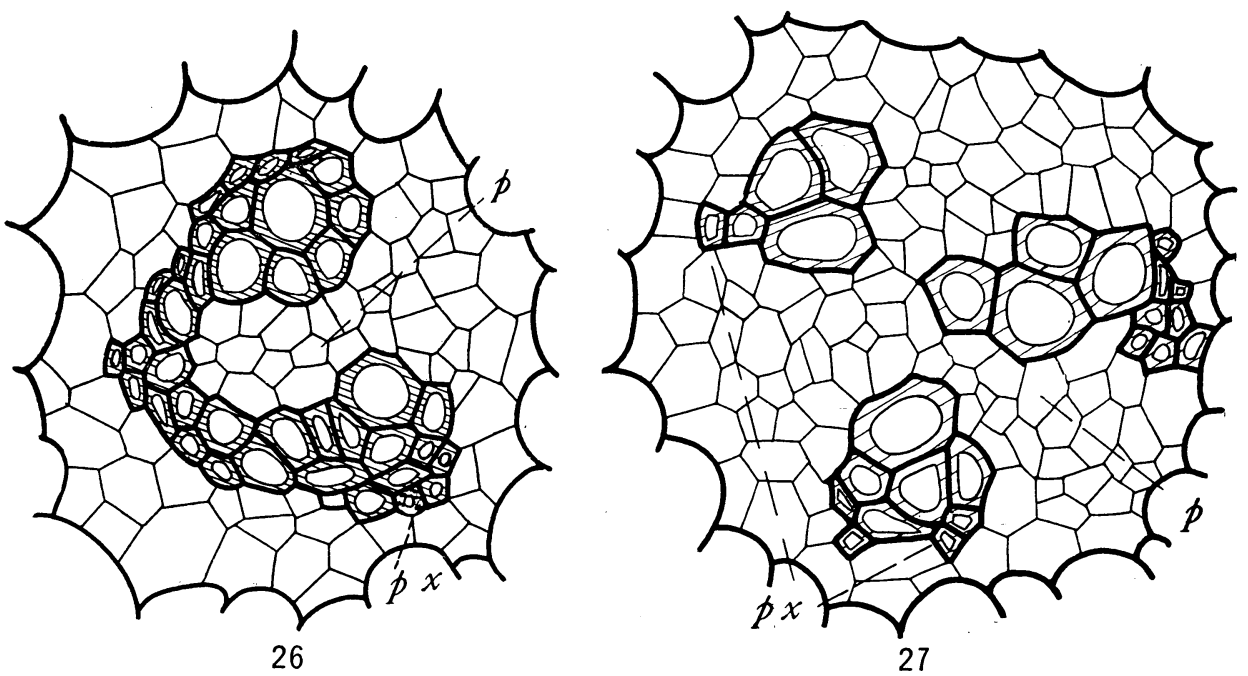

FIGS. 26, 27.-Fig. 26, L. verticillatum: transverse section, showing the development of the crescent-shaped xylem mass from the parallel-banded arrangement; $p x$, proto-

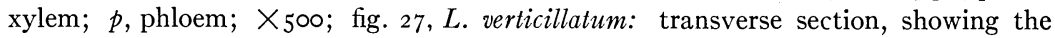
radial arrangement derived from the crescent-shaped xylem mass; $p x$, protoxylem; $p$, phloem; $\times_{5} \circ$.

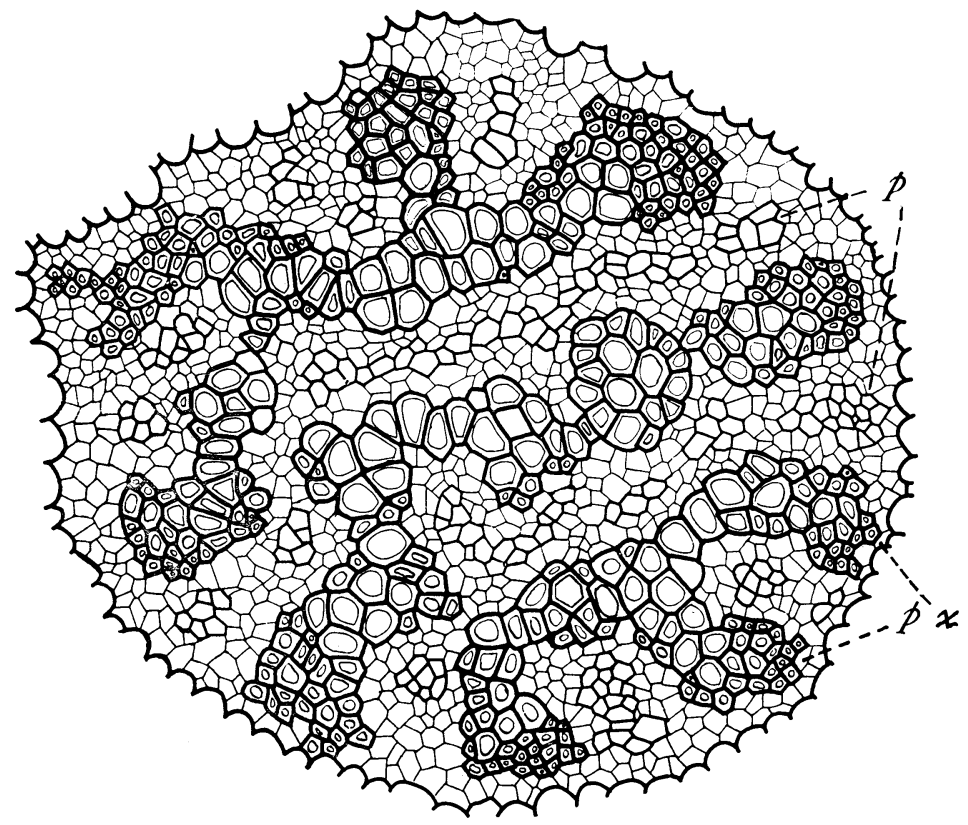

FIG. 28.-L. verticillatum: transverse section of the mature stem, showing the parallel-banded type of stele; $p x$, protoxylem; $p$ phloem; $\times 185$.

This content downloaded from 128.143.023.241 on August 23, 2016 22:07:51 PM 
between the protoxylem points and between the xylem bands (fig. 28).

\section{Discussion}

JoNEs, ${ }^{2}$ in an investigation of about a dozen temperate and tropical species of Lycopodium, found that the radial arrangement of the stele is very characteristic, especially in young plants. He says "the principal feature observed in sections of the young stem is that the vascular bundles present a triarch or tetrarch arrangement exactly similar to the structure which may be found in roots." He also states that it has always been suggested that this arrangement represents a very primitive type of stele. Jones also divides the mature stems into two categories: parallel-banded, connected with a high number of protoxylem groups; and a second type characterized by a promiscuous mixture of xylem and isolated phloem patches, which he regards as characteristic of tropical epiphytes.

Holloway, ${ }^{3}$ in a study of the young sporophytes of six New Zealand species of Lycopodium, classifies them as follows in regard to the type of stele: (I) a "mixed" type, with indiscriminate mixture of xylem and phloem; (2) a radially banded type, with the radial arrangement of xylem and bands of phloem situated between the xylem radii; and (3) the parallel-banded type, with the xylem and phloem arranged in alternating bands across the cylinder. He notes that the radial and parallel-banded types are closely related and may pass into one another, and that the latter is associated with a relatively high number of protoxylem points, $5^{-9}$ he says being sufficient to give that arrangement.

WIGGLESWORTH, ${ }^{4}$ from a study of young sporophytes of $L$. complanatum and $L$. clavatum, concludes that the radial arrangement of xylem and phloem occurring in upright forms of Lycopodium is the more primitive condition. In the upper part of the stem she

${ }^{2}$ Jones, C. E., The morphology and anatomy of the stem of the genus Lycopodium. Trans. Linn. Soc. II. 7:15-35. pls. 3-5. 1905.

3 Holloway, J. E., A comparative study of the anatomy of six New Zealand species of Lycopodium. Trans. N. Zeal. Inst. 42:356-370. pls. 32-34. I909.

${ }_{4}^{4}$ Wigglesworth, Grace A., The young sporophytes of Lycopodium complanatum and Lycopodium clavatum. Ann. Botany 21:211-234. pl.'22. 1907. 
found a triarch or tetrarch arrangement, with the three or four protoxylem groups connected with metaxylem, and in the base of the young plants there was a central core of xylem in the center of the stele.

BooDLE $^{5}$ investigated the stem structure of $L$. volubile and L. salakense. He regards the normal Lycopodium stele to be the parallel-banded type, as in L. volubile. L. salakense has the intermingling of xylem and phloem, resembling Gleichenia. He notes that in some cases the presence of the peripheral growth of the protoxylem forms a nearly continuous ring.

The present investigation extends the range of knowledge of the anatomical structure of Lycopodium by including some species not studied before, which show certain phases of stelar development to be especially emphasized. It emphasizes the fact that the radial arrangement of the stele is quite common, and that in many cases it is the original condition from which the parallelbanded type is derived. While this radial arrangement is probably the common one in Lycopodium, it is not the universal condition, and the great variability of the stelar structures in these epiphytic species deserves especial emphasis. It should also be kept in mind that the greater variability in structure occurs in the stele of the strobilus, while the vegetative steles remain relatively constant. The presence of a great variety of types of stele, radial, parallelbanded, crescentic, and that corresponding by definition to the amphivasal in the same plant, and even in the same stem, as occurs in $L$. carinatum, makes it clear that these types are more closely related than has been supposed.

Jones relates the parallel-banded type to the plagiotropic stems generally, but notes that there are some exceptions, as the orthotropic L. obscurum, which has the parallel-banded arrangement. Holloway points out that the parallel-banded arrangement is derived from the radial as a result of the branching stem. Both Jones and Holloway consider the radial arrangement characteristic of the stems of epiphytic species of Lycopodium.

5 Boodle, L. A., On the structure of the stem in two species of Lycopodium. Ann. Botany 14:3I5-3I7. I900. 
The present investigation shows that not all of the epiphytic species are characterized by the radial arrangement of the stele, since $L$. verticillatum has generally the parallel-banded type. Further, it shows that not only may both radial and parallelbanded types occur in the same stem, associated with crescentic and amphivasal, but that these changes from one arrangement to another are independent of the branching of the stem, as seen in L. carinatum, L. Phlegmaria, and L. varium. Branching does induce change from radial to parallel-banded arrangement, but this change may also occur without branching.

There seems to be a general opinion, as expressed by Jones and also by Holloway, that the parallel-banded type of stele is associated with a large number of protoxylem points, and this opinion may be completely justified by evidence drawn from the study of the young sporophytes. In the mature plants, in some of the species used in this investigation, the parallel-banded arrangement occurred where there were but 2, 3, and 4 protoxylem points; and in $L$. verticillatum the parallel arrangement started with but 2 protoxylem points. In these species the parallel-banded arrangement seems to be just as definitely associated with a small number of protoxylem points as in those studied by Jones and by HoLloWAY, where it was associated with a large number.

BoodLE regards the parallel-banded arrangement as the normal Lycopodium stele, but from this study it seems unsafe to regard any particular type of bundle arrangement as normal, since it will depend upon the level at which the stem is cut, or how near the section is to the point of branching as to what type of stele is found, for all the known Lycopodium steles may be found in the same stem excepting the so-called "mixed" stele.

Attempts have been made to connect the factors determining the stelar development with the type of stele found in the various species of Lycopodium. Plagiotropism has been suggested as being the factor favoring the formation of the parallel-banded type of stele, and orthotropism that favoring the development of the radial stele, but so many exceptions are to be found to these statements that they seem to lose significance. The conditions 
under which these epiphytic species grew are described as being about the optimum for vegetative growth. A definite structural evidence for rapid elongation in these plants is the close series in sporogenesis shown by serial transverse sections of the strobilus. It would seem then that these variations of stelar structure occur under conditions favoring rapid elongation. Whatever the conditions may be, the fact of the variations emphasizes the susceptibility of these species to conditions and the ability to modify the stelar development, which is generally regarded in most plants as rather a fixed structure.

\section{Summary}

I. From this investigation it may be concluded that the species of Lycopodium studied are characterized by great variability in the development and structure of the stele.

2. The radial stele may be considered as the prevailing type, and as the basis in most cases for modification to the other types found.

3. There are found radial, parallel-banded, crescentic, and amphivasal steles in the same strobilus axis in L. carinatum, and all types but the amphivasal in L. Phlegmaria and $L$. varium.

4. L. Billardieri is the most constant in its stelar structure, with a type of stele so characteristic as to make the species almost recognizable by the transverse section of the stem.

5. L. verticillatum has generally parallel-banded arrangement of stele, although the radial stele has been considered the prevailing type in epiphytic species.

6. All attempts to place the species of Lycopodium in definite categories based on the character of the stele are extremely uncertain, since there are exceptions in some species and even exceptions in different parts of the same stem in some species.

7. If the character of the stele is in any way dependent upon varying conditions, its use in phylogeny must recognize this fact.

8. The investigation confirms the idea that the radial arrangement of the stele, retained persistently by the root, is probably the most primitive stem arrangement, from which most known stems have departed. 
This investigation was undertaken at the Hull Botanical Laboratory, University of Chicago, and was completed under the direction of the staff of that institution. The writer wishes to express his thanks to Dr. J. M. Coulter for his constant advice and criticism, and to Dr. Charles J, Chamberlain and Dr. W. J. G. LAND for the material furnished for the investigation and for their criticism of the preparations and aid in interpretation.

Hull Botanical Laboratory

UNIVERSITY OF CHICAGO 